\title{
The Mango Shield Scale, Milviscutulus mangiferae (Green) (Hemiptera: Coccidae) - A New Invasive Soft Scale in Egypt
}

\author{
S. ABD-RABOU' and G. A. EVANS ${ }^{2}$ \\ ${ }^{1}$ Agricultural Research Center, Plant Protection Research Institute, 7 Nadi El-Seid, Giza, Egypt \\ ${ }^{2}$ USDA/APHIS/NIS, 10300 Baltimore Ave BARC-West, Bldg. 005, Rm. 09A, 20770. Beltsville, MD, USA
}

(Received: 12 October 2017; accepted: 13 November 2017)

\begin{abstract}
The mango shield scale, Milviscutulus mangiferae (Green) (Hemiptera: Coccidae), a serious pest of mango trees in various parts of the world, is reported on Mangifera indica in Egypt which represents the first record of this species in the country.
\end{abstract}

Keywords: Soft scale, new record, Milviscutulus mangiferae, mango, Egypt.

The mango shield scale, Milviscutulus mangiferae (Green) (Hemiptera: Coccidae) is a very polyphagous species, known to feed on 42 different families and 82 different genera of plants including papaya (Carica papaya), avocado (Persea americana), breadfruit (Artocarpus altilis), Syzygium spp., Vanilla sp., guava (Psidium guajava), coconut (Cocos nucifera), orange and lemon (Citrus sinensis, C. limon) (Williams and Watson, 1990; García Morales et al., 2016). Green (1889) described the species from specimens collected on mango in Sri Lanka, and occurs throughout tropical and subtropical zones of the world. It has been found in the Western Palearctic region in Israel (Kfir and Rosen, 1980; Wysoki et al., 1993; Wysoki, 1997) and in Italy (Pellizzari and Porcelli, 2014), furthermore it has been intercepted in the Netherlands (Jansen, 1995) and the UK (Anderson and MacLeod, 2008). This soft scale insect is a serious pest of mango trees in various parts of the world (García Morales et al., 2016) and has a great potential to invade other countries of the world due to its small size, wide host range, and association with plants that are often imported from areas where it occurs.

This species damages mangos by direct feeding on the plant juices and by the reduction of photosynthetic capacity as a result of its production of 'honeydew' and the subsequent growth of sooty mold on the leaves. Heavy infestations may result in reduced tree vigour and leaf size, causing yellowing of the leaves, leaf drop and death of branches (Peña and Mohyuddin, 1997).

\footnotetext{
* Corresponding author; e-mail: shaabanabdrabou59@yahoo.com
} 


\section{Materials and Methods}

Infested leaves and stems of mango trees were examined in the field using a pocket magnification lens. Infested leaves and stems were also collected from different governorates of Egypt, Daqahliya, (northeast of Cairo), Gharbia (north of the country). Ismailia (northeastern part of the country) and Sharqyia (central and east Delta region) in Egypt during 2017. The samples placed separately in paper bags for further examination in the laboratory. Identification of soft scale insects was then made by examining adult that were slide-mounted in Canada balsam, following the methods described in Abd-Rabou (1997) identification of materials was based on key of Williams and Watson (1988).

\section{Results and Discussion}

Collected materials indicated that Milviscutulus mangiferae (Green) was found on Mangifera indica in New Salhia (30 37' 47. 18" N $31^{\circ} 56^{\prime} 27.67^{\prime \prime}$ E) situated in the eastern part of the Nile Delta Markaz Al Hesinyah Sharqyia and represents the first record of the establishment of this species in Egypt.

\section{Genus Milviscutulus Williams and Watson, 1990:}

Genus Milviscutulus is similar to the genus Protopulvinaria Cockerell in that it has exceptionally elongate anal plates, three stigmatic setae at each stigmatic cleft and by having a considerable number of tubular ducts. It differs from Protopulvinaria which has a dense submarginal band of tubular ducts and the anterior-lateral margin (am) of each plate 3.5 times (usually 4-5x) longer than the postero-lateral margin (pm); whereas Milviscutulus has fewer tubular ducts which are scattered (not in a dense band) and the anal plates are not as elongate with the anterior-lateral margin of each plate 1.7-3.3 times (2 times in M. mangiferae) longer than the postero-lateral margin.

\section{Milviscutulus mangiferae (Green) (Hemiptera: Coccidae):}

Anal plates located near hind pair of legs; anterior margin of anal plates conspicuously longer than posterior margin; body triangular; dorsal setae capitate; marginal setae fringed; multilocular pores predominantly with 7 or 8 loculi; multiloculars restricted to vulvar area; ventral tubular ducts medial between legs, with diffuse submarginal band on abdomen; legs small, with tibio-tarsal sclerosis, but not articulated; mouthparts frequently oriented to 1 side of body. Other characters: Claw without denticle; claw digitules equal in size; 1 pair of prevulvar setae (often obscured by anal plates); 6-14 submarginal tubercles around body margin; stigmatic setae differentiated from other marginal setae middle seta longer than lateral setae; each anal plate with 4 apical setae, without a subdiscal seta; with 1 subapical seta on each plate; anal fold with 4 fringe setae; antennae 6-, 7-, or 8-segmented; preopercular pores in small numbers, inconspicuous. Milviscutulus mangiferae is similar to M. ciliatus Williams and Watson by having similarly shaped and positioned 
anal plates and a triangular body shape. M. mangiferae differs by having the apices of the marginal setae strongly frayed (slightly frayed in $M$. ciliatus) and straight (curved in M. ciliatus). Milviscutulus mangiferae is also similar to Protopulvinaria longivalvata in body shape and the position of the anal plates on the dorsum but differs by lacking distorted coxae (present in P. longivalvata), and shorter anal plates (long in P. longivalvata). (Fig. 1).

Key to the species of genus Milviscutulus:

This genus contains 4 species $-M$. ciliatus, M. pilosus and M. spiculatus were all described by Williams and Watson 1990 from the Pacific Islands, while M. mangiferae was described from Sri Lanka and is a cosmopolitan species.

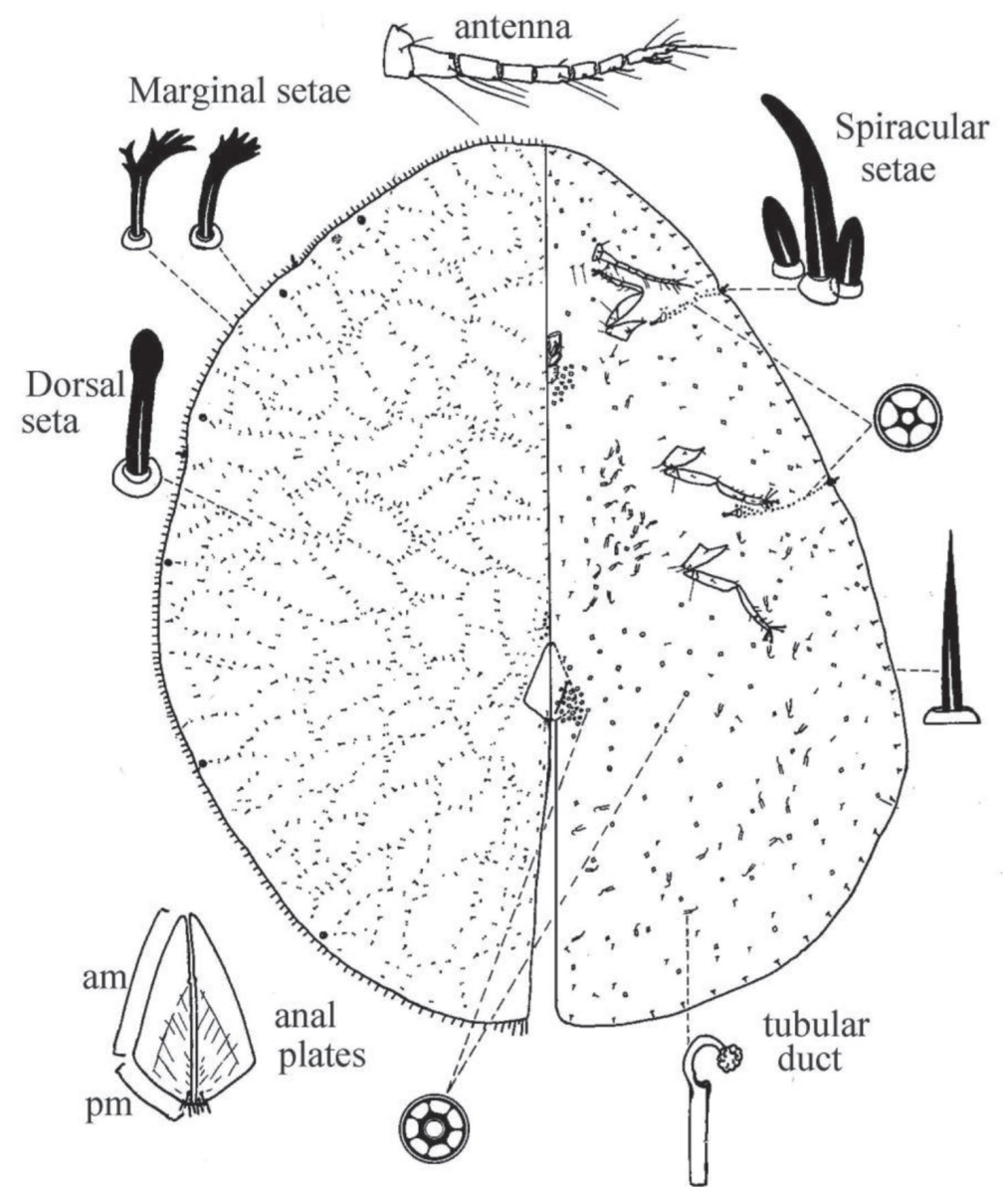

Fig. 1. Milviscutulus mangiferae adult female (modified from Hamon and Williams, 1984) 


\section{Key to the species (after Williams and Watson, 1988)}

1. Dorsal setae 19-65 $\mu \mathrm{m}$ long and flagellate ....... pilosus Williams and Watson

1b. Dorsal setae 5-17 $\mu \mathrm{m}$ long, usually at least some lanceolate, clavate or capitate ..................................................................................... 2

2(1b) Marginal setae mostly as long as, or longer than, central stigmatic seta, sometimes strongly curved towards posterior end of body

ciliatus Williams and Watson

2b. Marginal setae appreciably shorter than central stigmatic seta, or if a few are as long as central stigmatic seta, then these are straight or only slightly curved

3 (2b) Some or all dorsal setae clavate or capitate with blunt or sharp tips; marginal setae mostly fringed or fimbriate mangiferae (Green)

3b. Dorsal setae flagellate or lanceolate with sharp tips, never bluntly clavate or capitate;

marginal setae mostly simple, only a few with slight fraying of the tips.

spiculatus Williams and Watson

\section{Acknowledgment}

We thank Éva Szita (Hungarian Academy of Sciences, Centre for Agricultural Research, Plant Protection Institute, Budapest, Hungary) for her excellent suggestions and review of this manuscript.

\section{Literature}

Abd-Rabou, S. (1997): Key to the species of whiteflies from Egypt (Homoptera: Aleyrodidae). Bull. Soc. Ent. Egypt, 75, 38-48.

Anderson, H. and MacLeod, A. (2008): CSL Pest Risk Analysis for Milviscutulus mangiferae. https://secure. fera.defra.gov.uk/phiw/riskRegister/downloadExternalPra.cfm?id=3886

García Morales, M., Denno, B. D., Miller, D. R., Miller, G. L., Ben-Dov, Y. and Hardy, N. B. (2016): ScaleNet: A literature-based model of scale insect biology and systematics. Database. doi: 10.1093/database/ bav118. http://scalenet.info [accessed on 2/11/2017].

Green, E. E. (1889): Descriptions of two new species of Lecanium from Ceylon. Entomologist's Monthly Magazine $25,248-250$.

Hamon, A. B. and Williams, M. L. (1984): The soft scale insects of Florida (Homoptera: Coccoidea: Coccidae). Arthropods of Florida and neighboring land areas. Florida Department of Agriculture and Consumer Services, Gainesville, Florida, Vol. 11, 194 p.

Jansen, M. G. M. (1995): Scale insects (Homoptera: Coccinea) from import interceptions and greenhouses in the Netherlands. Israel J. of Entomol. 29, 131-146.

Kfir, R. and Rosen, D. (1980): Biological studies of Microterys flavus (Howard) (Hymenoptera: Encyrtidae), a primary parasite of soft scales. J. Entomol. Soc. of Southern Africa 43, 223-237.

Pellizzari, G. and Porcelli, F. (2014): Alien scale insects (Hemiptera Coccoidea) in European and Mediterranean countries: the fate of new and old introductions. Phytoparasitica 42, 713-721. DOI 10.1007/s12600-0140414-5

Peña, J. E. and Mohyuddin, A. I. (1997): Insect pests. In: R. E. Litz (ed.): The Mango: Botany, Production and Uses. CAB International, Wallingford, UK, pp. 327-362. 
Williams, D. J. and Watson, G. W. (1988): The Scale Insects of the Tropical South Pacific Region. Part. 2: The Mealybugs (Pseudococcidae). CAB International, Wallingford, UK.

Williams, D. J. and Watson, G. W. (1990): The Scale Insects of the Tropical South Pacific Region. The Soft Scales (Coccidae) and Other Families. Part 3. CAB International, Wallingford, UK.

Wysoki, M. (1997): Present status of arthropod fauna in mango orchards in Israel. Acta Horticulturae 455, 805-811.

Wysoki, M., Ben-Dov, Y., Swirski, E. and Izhar, Y. (1993): The arthropod pests of mango in Israel. Acta Horticulturae 341, 452-466. 
